\title{
トリム及び吃水の図的計算法について
}

\section{On the Graphical Calculation of the Trim and Drafts.}

\section{杉 原 喜 義（水産講習所）}

\begin{abstract}
The change of trim and the resultant drafts due to adding or deducting weight have been determined by calculation as usually.

In this pafer the author suggests a method of determining, more simply and speedily, the above mentioned amounts by means of chart work.

For the purpose two nomographic charts are drawn by modifying the hydrostatic curves of the ship.

The above charts, as some examples; for 500 G.T. Fish carrier, 3,500 G, T, . Refrigerated whale meat carrier and $17,000 \mathrm{G}, \mathrm{T}$, whale factory ship are shown in appendix,
\end{abstract}

\section{1, 前 かi き}

船船の荷役に依るトリムの変化及びこれによる船首屁の吃水の計算には周知の如く一般に次式 が用いられている。

$$
\begin{aligned}
& F=F_{0}+\frac{w}{T}+\frac{w l}{M}\left(\frac{1}{2}-\frac{f}{L}\right) \\
& A=A_{0}+\frac{w}{T}-\frac{w l}{M}\left(\frac{1}{2}+\frac{f}{L}\right)
\end{aligned}
$$

とこで

$F, F_{0}$ : 夫夫荷役後及び荷役前の船首吃水
$A, A_{0}$ :
" 船首吃水

$T$ ：短糎 (邓は吋) 排水屯数

$M$ ：铮粧（欢吋）トリム゙モーメント

$L \quad$ ：船首尾垂線間の船の長さ

$f \quad$ :

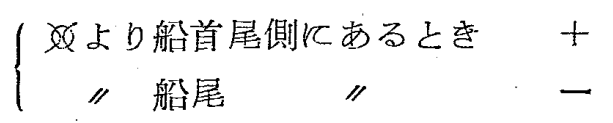

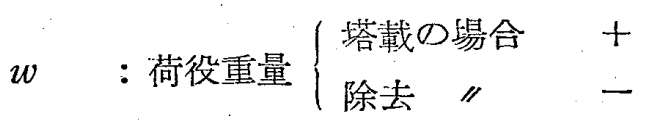

$l$ : 浮面心上り重量塔載 (叉は除去) 点をでの距離

$$
\left\{\begin{array}{cc}
\text { 浮面心上り船首側 } & + \\
\| & \text { 船尾側 }
\end{array}\right.
$$

上式は簡単ではあるが，乙れ者使用するとは，Fig，1 亿示す様な排水量等諸曲線から其の都

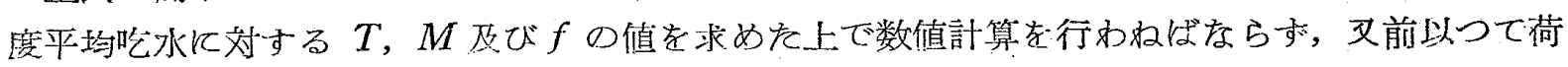


役後の吃水を予定しての重量配分計 画には必和しも簡単でをん。

そこで著者は上の計算式を図表化 し此の图表上で禹脚器亡定規を用い る所謂 Chart work 飞依つて直観 的飞早く然か子比較的正確さを为子 て荷役の計画及び計算を行い得るこ とを提唱し諸賢の御批判を仰ぐ次第 である。

\section{2，図表の作製}

図表の作䡈には先づ上の計算を次 の二段原分ける。

(i), $t=\frac{w l}{M}$ 飞佂つて $\operatorname{trim} t$

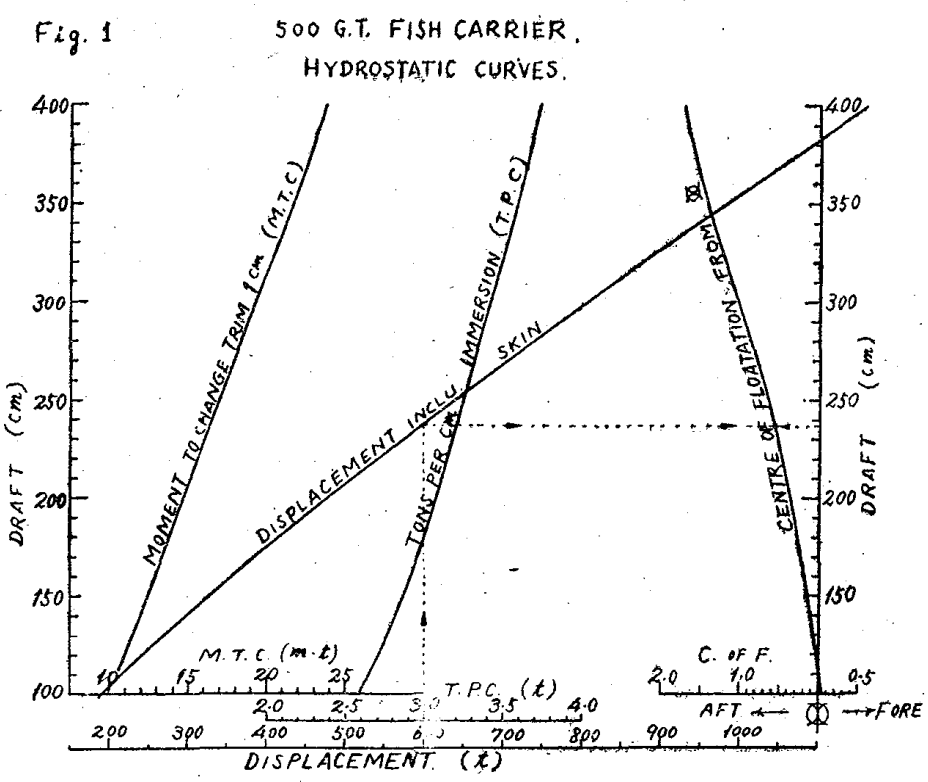

求める.

(ii)，(i)で求めた trim を船首尾吃水の変化に配分する。

(i)の訫算には普通の Nomogram 1) に依る方法考採つた。即ちとこでは Fig.2の例に示す如

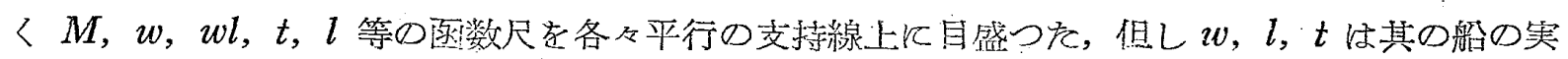

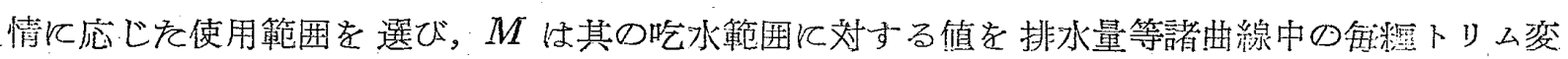
化モーメント曲線より取り更に此の $M$ の種々の值に相当する吃水の目盛を $M$ 目盛の片側に記大 すれば以後の実際計算には $M$ 目盛は不必要亡なる。

(ii）の計算には次の様を図表を用いた。

Fig.3 の例に示す様に適当な縮尺で船の長さ $L$ を横の base line 上飞さり A.P., X.P.

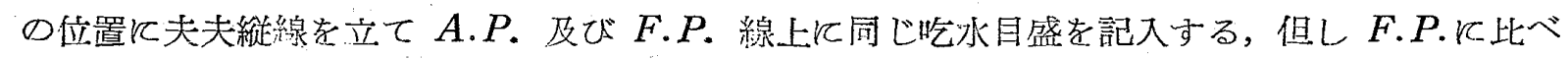
stem の傾斜が大きい場合は縦横の縮尺に応じを stem line を画き此の上飞子吃水目盛を入れ る. 目盛の範国忹計画整荷状態で trim しそ場合の最低吃水を下限に，满載状態で trim しを場

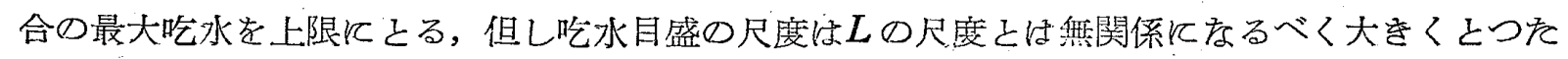
方が便利である。

次に其の船の排水量等諸曲線の中から浮面心曲線をとり各吃水に态じて $\boldsymbol{L}$ と同尺度で此の园表

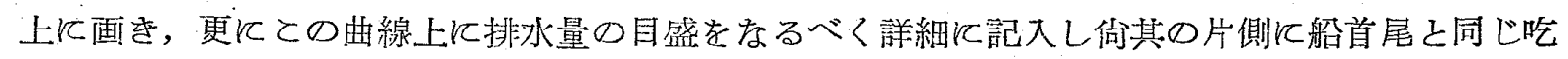
水目盛を入れる。排水量目盛を記入するとは，例えば Fig.1 の排水量 600 ton 飞相当する縦線 之排水量曲線之の交点加吃水 $237 \mathrm{~cm}$ 反奶応するから浮面心曲線上の対応吃水 237 の位置に 600

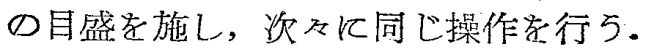

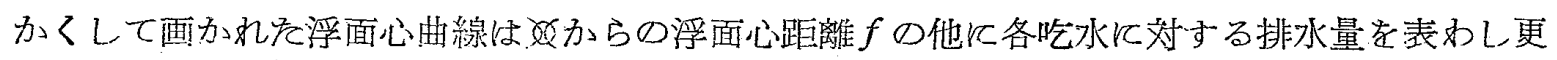

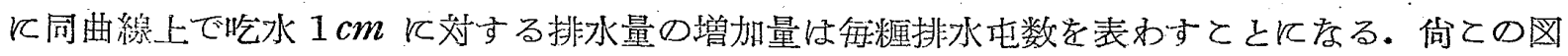
表の上部か下部の適当存場所火 Fig.3 の例《示す様に其の船の Profile 及び Hold の位置等を 画んて和く亡更に便利であると思われる。

以上の様にして作製した2枚の図表の害例 500 屯型魚類運搬船，3,500 屯型鯨肉冷凍運搬船 及び 17,000 屯型鯨工船に就き夫夫 Figs.2,3；Figs.4, 5 及び Figs.6,7 亿示した. 倚参考のため , 上の备船の主要目次表泟示す。 


\begin{tabular}{|c|c|c|c|c|c|}
\hline \multicolumn{2}{|c|}{ Item } & Ship & Fish Carrier. & $\begin{array}{c}\text { Refrigerated } \\
\text { Whale meat } \\
\text { Carrier. }\end{array}$ & $\begin{array}{l}\text { Whale } \\
\text { Factory } \\
\text { Ship. }\end{array}$ \\
\hline \multicolumn{2}{|c|}{ Length. p. p. } & $(m)$ & 50.26 & 99.80 & 175.00 \\
\hline \multicolumn{2}{|c|}{ Breadth. } & $(m)$ & 8.40 & 15.00 & 23.40 \\
\hline \multicolumn{2}{|c|}{ Depth. } & $(m)$ & 4.20 & 8.00 & 17.20 \\
\hline \multicolumn{2}{|c|}{ Gross ton. } & . & 521.91 & $3,689.31$ & $16,777.09$ \\
\hline \multicolumn{2}{|c|}{ Fish hold } & $\left(m^{3}\right)$ & 580.2 & 2,593 & $\begin{array}{l}\text { whale oil } \\
26,003\end{array}$ \\
\hline \multicolumn{2}{|c|}{ Fuel oil t. } & $(m)$ & 166.8 & 1,345 & 1,920 \\
\hline \multicolumn{2}{|c|}{ Fresh water t. } & $\left(m_{3}\right)$ & 85.4 & 947 & 2,901 \\
\hline \multirow{4}{*}{ 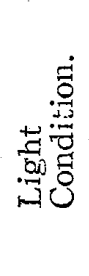 } & Draft. & $(m)$ & 2.23 & 3.19 & 4.01 \\
\hline & Trim by & & 2.08 & 1.72 & 3.91 \\
\hline & Disp. & $(t)$ & 556.64 & 3,159 & 12,264 \\
\hline & M. T. C. & $(t-m)$ & 15.85 & 58 & 328 \\
\hline \multirow{4}{*}{ 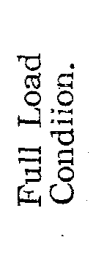 } & Draft. & $(m)$ & 3.39 & 6.38 & 10.79 \\
\hline & Trim by & & 1.17 & 1.51 & 1.31 \\
\hline & Disp. & $(t)$ & 950.92 & 7,274 & 36,640 \\
\hline & M. T. C. & $(t m)$ & 21.2 & 93.5 & 470 \\
\hline
\end{tabular}

\section{3. 図表の使用法}

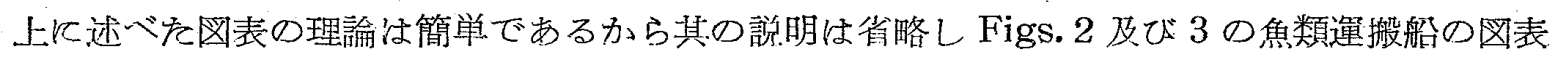
を例にとつて其の使用法を述べる。

\section{例 1 . 船首尾吃水を知つて其の時の排水量を求む。}

今船首吃水 $F_{0}=124 \mathrm{~cm}$, 船尾吃水 $A_{0}=320 \mathrm{~cm}$ 亡する上 Fig. 3 の stem line 及び A.P.上 そ夫夫 $F_{0}$ 及び $A_{0}$ の点をとり，との二点告結ぶ直線と浮面心曲線との交点に依つてとのときの 排水量目盛 $W_{0}=550 \mathrm{t}$ 之相当吃水 $222 \mathrm{~cm}$ 得る. 乙の昜合 $\overline{A_{0} F_{0}}$ 多超長するとF.P.上の吃水 $120 \mathrm{~cm}$ を得るから平均吃水は $220 \mathrm{~cm}$ であるが，乙れ対する排水量修正量は考える必要がなく

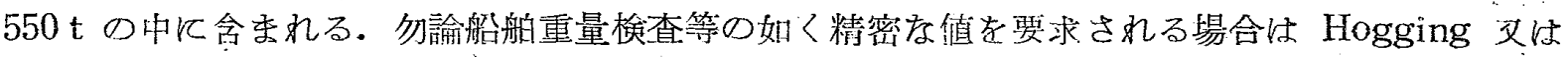
Sagging 等船体の Deflection を考慮し Bonjean curve 飞依つて算走する必要があるが普通 の荷役計画等の昜合は上の方法で実用上差支えなんと考える。

上の状態をるとると次の通り

$\left.\begin{array}{l}\text { 船首吃水 } F_{0}=\left\{\begin{array}{l}120 \mathrm{~cm} \text { at } F . P . ※ \\ 124 \mathrm{~cm} \text { at stem }\end{array}\right. \\ \text { 船尾吃水 } A_{0}=320 \mathrm{~cm} \\ \text { 排 水 量 } W_{0}=550 \mathrm{t} \\ \text { 浮面心距離 }=-0.5 \mathrm{~m}\end{array}\right\}$

簿註 ※以下計算の便宜上特記の他は船首吃水は F.P.上の值をとる. 


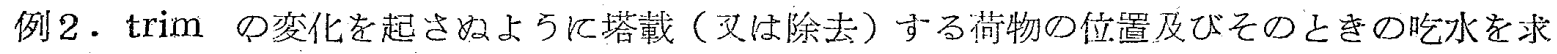
t.

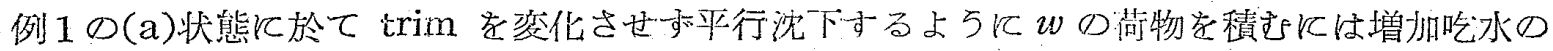
平均飞対する水線面の浮面心位置即ち Fig. 3 の浮面心曲線上で $\left(W_{0}+\frac{w}{2}\right)$ の位置子選べ代実

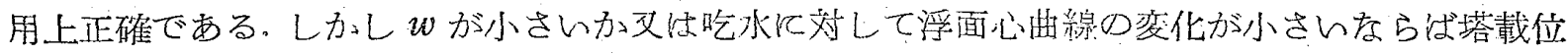

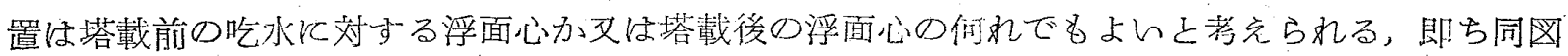

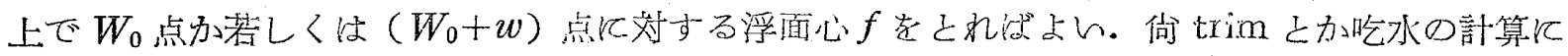

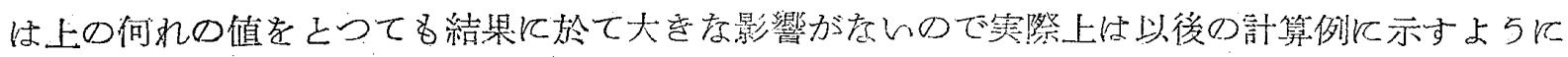
塔載後（又除去後）の值索とつを方が便利である。

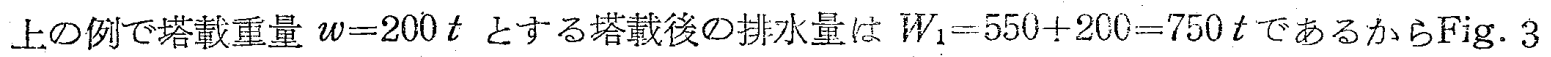
の浮面心曲線上の $W_{1}$ 点を通り $F_{0}, A_{0}$ 飞平行線を引き $F . P$. 度び $A . P$. 之の交点に低つて船

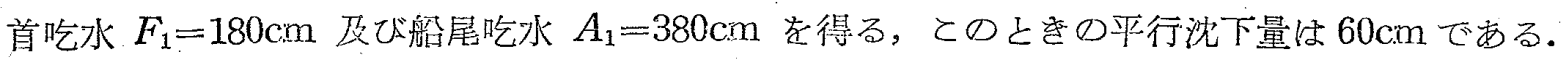

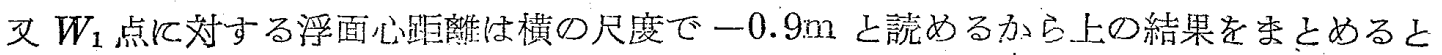

船首吃水 $F_{1}=180 \mathrm{~cm}$

船尾 " $A_{1}=380 \mathrm{~cm}$

排水量 $W_{1}=750 \mathrm{t}$

浮面心距離 $=-0.9 \mathrm{~m}$

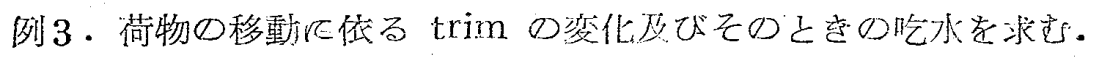

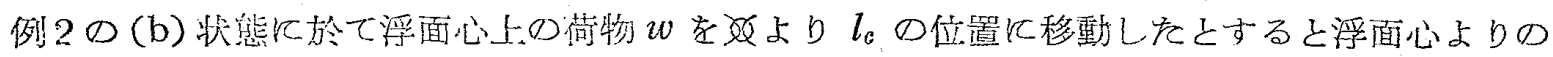

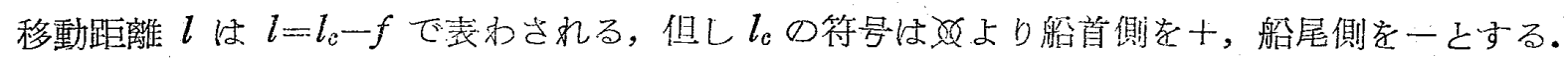

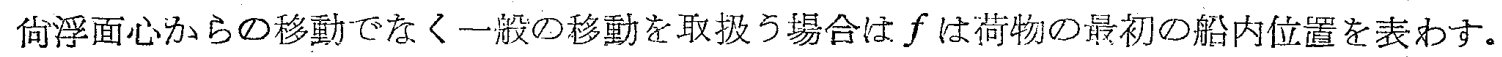

上の例で $w=200 \tau, l_{c}=6.1 \mathrm{~m}$ とすると $l=6.1-(-0.9)=7.0$ であるから. trim moment は $w l$ となり，とれは Fig. 2 亿於て $w$ 尺上の目盛 200 と $l$ 尺上の目盛 7.0 とを結び $w l$ 尺之の交点 の目盛を読んで 1400 を得る：次に Fig. 3 の浮面心曲線上 $W_{4}=750$ 亿相当する吃水目感 283 を

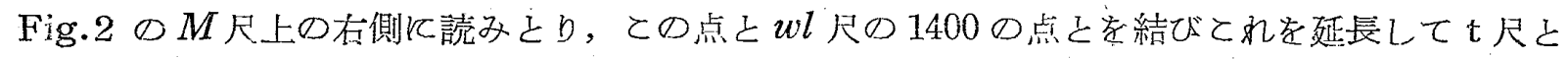
の交点の読み $75 \mathrm{~cm}$ を得る。乙れが即ち求める trim の変化量である. 更にとの trim 変化を

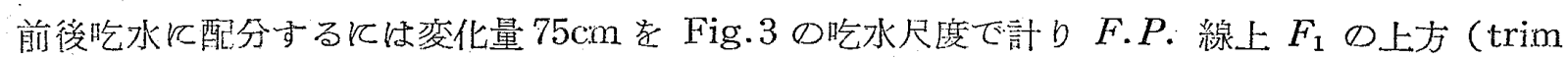
momentが一の場合㤌下方) Kとbとの点を $F_{1}^{\prime}$ とし, $W_{1}$ 点を通り $A_{1} F_{1}^{\prime}$ 飞平行に $A F$ を引 げ゙ A.P.上の $A$ 点即ち船尾吃水 $=344 \mathrm{~cm}$, stem line 上の $F$ 点即ち船首吃水 $=221 \mathrm{~cm}$ 老得 る.との結果を势えめると
船首吃水 $F=221 \mathrm{~cm}$ at stem
船尾吃水 $A=344 \mathrm{~cm}$
排水量 $=750 \mathrm{t}$
浮面心距離 $=-0.9 \mathrm{~m}$

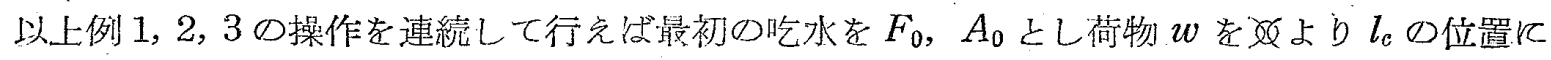

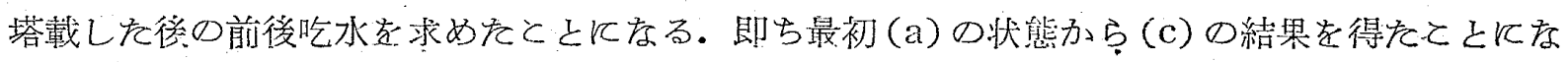
る.

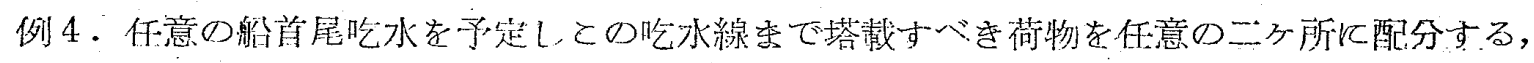


各々の重量救む。

上の例に上つて始めの状侦学（c）亡し，乙れ満載状態（船首吃水 $=280 \mathrm{~cm}$ ，船尾吃水 $=390$

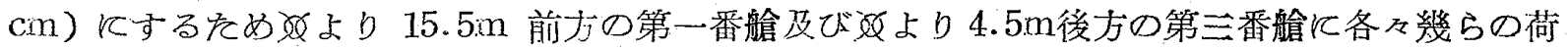
物孝積み得るか反就いて考光る。

Fig.3 の F.P. 艾び A.P. 上に夫夫満載吃水の值をとりとの二点を結ぶ直線と浮面心曲線と

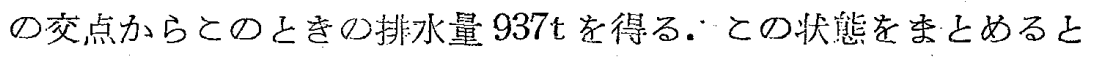

船首吃水 $F_{2}=280 \mathrm{~cm}$

船尾吃水 $A_{2}=390 \mathrm{~cm}$

排水量 $=937 t$

相当吃水 $=338 \mathrm{~cm}$

浮面心距離 $=-1.35 \mathrm{~m}$

依つて新飞塔载し得る全重量は次の通り

$$
w=937-750=187 \mathrm{t}
$$

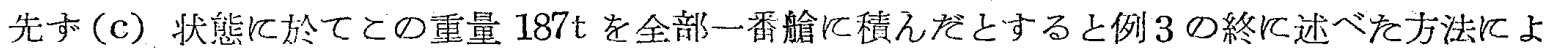
b次の状隼を得る。

$\left.\begin{array}{l}\text { 船首吃水 } F_{3}=350 \mathrm{~cm} \\ \text { 船尾吃水 } A_{3}=326 \mathrm{~cm} \\ \text { 其の他は (d) } \mathrm{k} \text { 同 じ }\end{array}\right\}$

との (e) 状態を予定の (d) 状態江するをめの trim の変化は

$$
(390-280)-(326-350)=134 \mathrm{~cm}
$$

亡なる，又は図上で $A_{2}$ を通り $A_{3} F_{3}$ に平行線を引くことに依り同じ値を得る.

次にこれだけの trim 变化を起すをめに一番艙から三番艙光移動すべき重量を求める，乙の間 題は重量移動距離, trim の変化, 排水量飞奶応する吃水等が既知であるから例 3 の方法を逆に 行らこ上に上り移動重量 142 を得る。従つて

一番艙 ( より $15.5 \mathrm{~m}$ 前方) $飞 \quad 187-142=45 \mathrm{t}$

三番艙 ( " $4.5 \mathrm{~m}$ 後方) $飞 \quad 142 \mathrm{t}$

を塔載すればよんことになる。

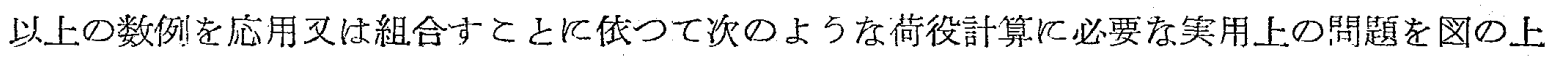
で解くここが出来る。

(i) even keel とするをめに䑰内に移動すべき重量又は其の移動距離.

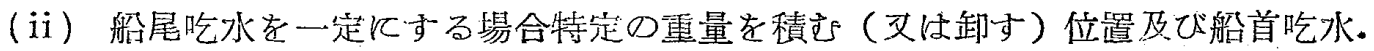

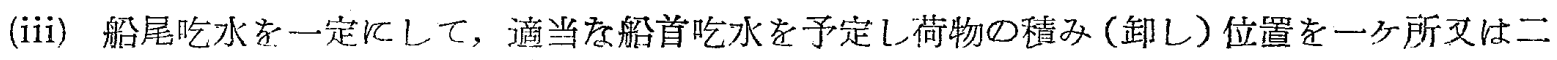
ろ所定めて其の各々飞積む（卸す）べき重量.

\section{4, 結 び}

园表に依る上の計算に於ては trim 等の計算図表は対数尺を使用し,てんる関係上 $w, l$ 等の值が

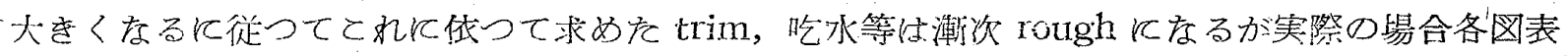

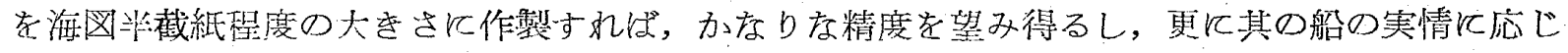
を小範国に止め，乙れ以上の重量の場合は二段階に分けて図表を使用すれば一層精密な值を得る ことが出来る。

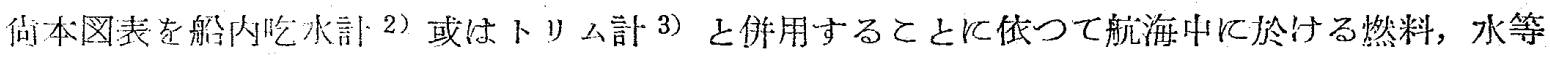


の消費を計画的に行らことが出来る。

本図表は trim 関係のみに止めをが浮面心曲線の他に縱の浮心曲線を画き，同時に $\frac{w l}{W}=\overline{B B^{\prime}}$

(但し $W=$ 排水量， $\overline{B B^{\prime}}$ 二浮心变化量）の計算図表を作製すれば trim を生じをときの船の重心

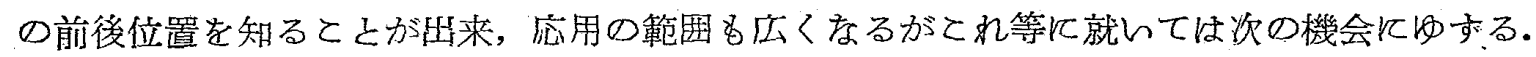

参考文 献

1) 例兑ば

谷村豊太郎著：団表学綱領，丸美，昭和 3 年.

小鉒金之助著 : 計算図表, 岩波全畫, 1951.

2) 船船工学便覽第 3 分册, $p .375$.

3) 鈴杢 揵：トリム計の考案について，日本航海学会誌第10号，昭和 29 年 4 月.
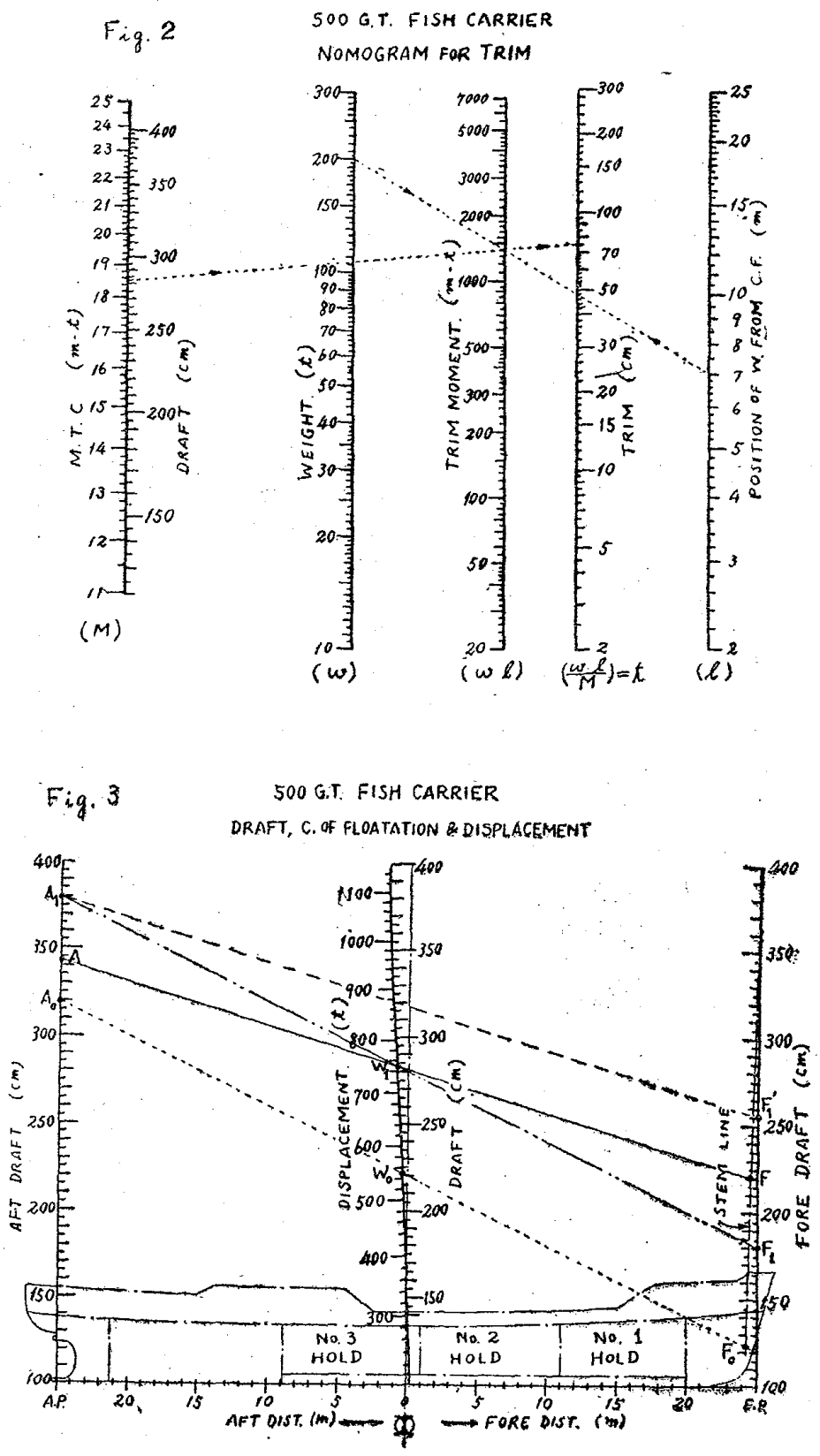

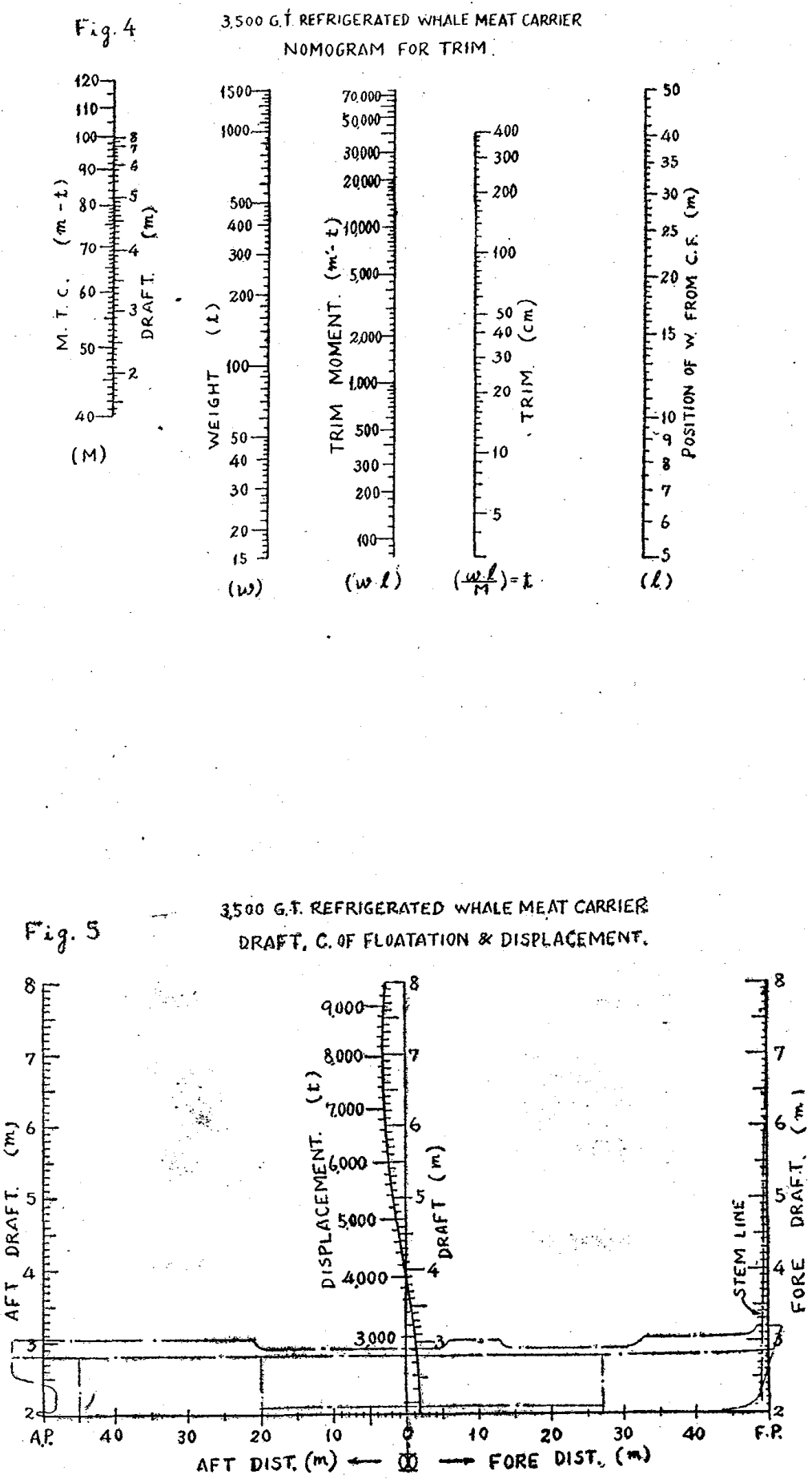


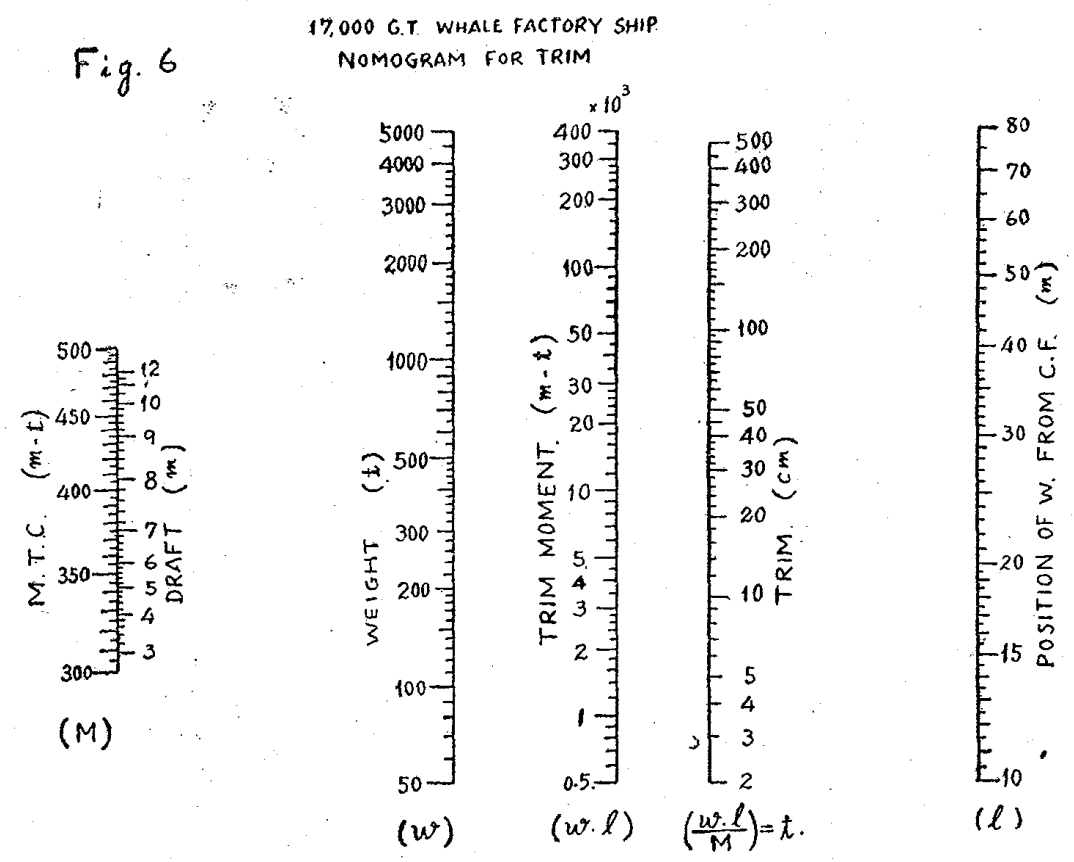

Fig. 7 DRAFT, C., OF FLOTATATION \& DISPLACEMENT.

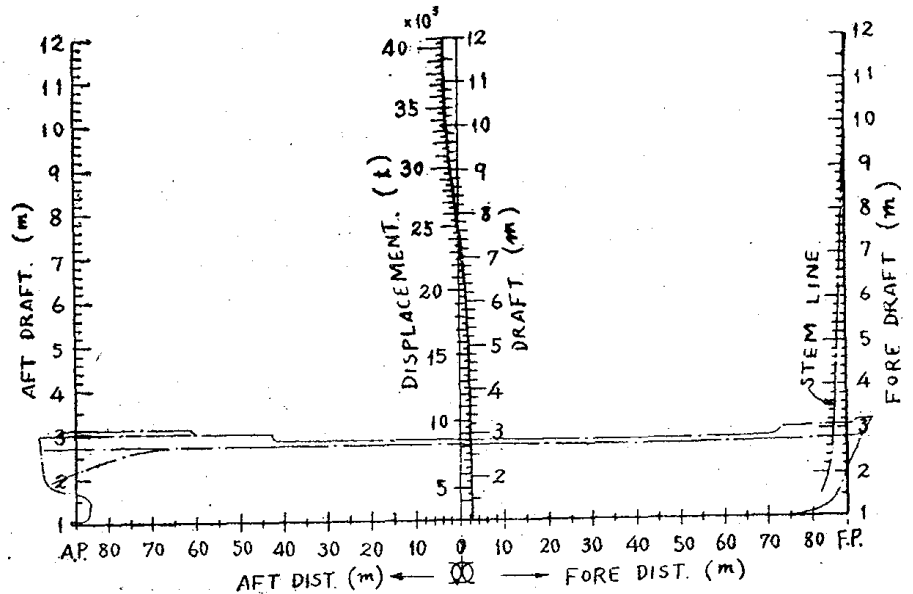

